\title{
Archeological tourism as a segment of cruise tourism offer on the example of Roman mosaics sites in Risan in the Bay of Kotor
}

\author{
Goran Radović ${ }^{1 *}$ and Nikola Konjević $^{2}$ \\ ${ }^{1}$ Faculty of Architecture, University of Montenegro, Podgorica, Montenegro \\ ${ }^{2}$ Faculty of Mediterranean Business Studies, Tivat, Adriatic University, Bar, Montenegro
}

\begin{abstract}
Cruise tourism, most often, is related to the landing of a ship in one or more ports, i.e. tourist destinations, in which passengers and crew go ashore. In the richness of the offer that a port in the Adriatic and the Mediterranean offers to cruise tourists is certainly the part that can be called: culture, tradition, monuments, by which the areas on the map of world cruises are recognized. The port of Kotor, which is the main port for the reception of cruise ships in Montenegro, has for years achieved significant results in the reception and dispatch of cruise ships. Thus, through the port of Kotor, during 2018, 412 ships carrying 492,475 passengers visited Montenegro. The paper, through the example of the Roman Mosaic site in Risan in the Bay of Boka Kotorska, analyses the effects of organized visits by tourists from cruise ships arriving to Kotor, and the importance and value of archeological sites in tourist cruising offer and the interaction between business and culture. The archeological site in Risan with the remains of the Roman Villa Urbana with preserved floor mosaics from the 2nd century represents a significant and attractive segment in the offer and development of archeological tourism as a subset of cultural tourism.
\end{abstract}

\section{Introduction}

Looking at the relevant decades-long data on the development of the cruise industry, one can conclude without a doubt that it has a tendency of continuous growth. Although the economic crisis of 2009, as in other forms of tourism, has temporarily slowed growth, the recovery has followed in the coming year.

The port of Kotor is the only port in Montenegro specialized in the reception and shipping of cruise ships and tourists. It belongs to the Mediterranean ports, of which the Adriatic is a significant segment. It can be said that Kotor, like other ports located in the Mediterranean, has numerous advantages over other cruise destinations, of which the possibility of ships staying near the city centers, which is most evident in Kotor. This allows travelers to visit a multitude of cultural monuments and religious sites or enjoy a variety of specific excursions organized in attractive surrounding locations in a short period

* Corresponding author: rgoran.arch@gmail.com 
of time. A special privilege for tourists is the Mediterranean type of climate, characterized by hot dry summers and warm, humid winters. This is an advantage that allows you to organize visits to this tourist destination, almost throughout the year.

The foregoing characteristics of the Mediterranean, as well as the growing understanding of the importance of this industry for the development of countries gravitating to the sea, also influenced the formation of the MedCruise Association, as the Mediterranean Cruise Port Association (MedCruise (2019-20), Yearbook, MedCruise Association, Muelle Ribera S/N Ed. Puerto-Ciudad, 5B Santa Cruz de Tenerife, 38001 Canary Islands, Spain)

. The mission of the association is to: promote the cruise industry in the Mediterranean and adjacent seas; helping its members benefit from the sustainable growth of the cruise industry as well as networking, promotion and professional development opportunities. The Association today has 71 full-time members, representing more than 100 ports, plus 30 associate members, representing other associations, tourist boards and shipping / port agents. Luka Kotor, by Decision of the 40th General Assembly, became a member of this Association in 2012. Kotor has a very long tradition of the Adriatic cruise port, which positively influences the affirmation of the cultural offer, the old Montenegrin capital Cetinje and the tourist and catering facilities of the coastal settlements of Perast and Sveti Stefan. Significant investments in infrastructure after the 1979 earthquake, when the operational coast of the port of Kotor was reconstructed and extended, as well as increasing the depth along the coast in 2001, created the conditions for accommodating larger ships. After 2014, the construction of the port passenger terminal facility provided the conditions for work of all state bodies; high quality reception and departure of passengers and crew, as well as increased volume and quality of the offer. All of the above is directly reflected in the financial effects generated by the provision of services in the port, the City of Kotor and Montenegro, which fall into the category of extra-board consumption.

\section{Basic indicators of vessel traffic in the port of Kotor}

Over the 10-year period (2008-2018), 3,511 cruise ships sailed through the port of Kotor. (Figure 1). 


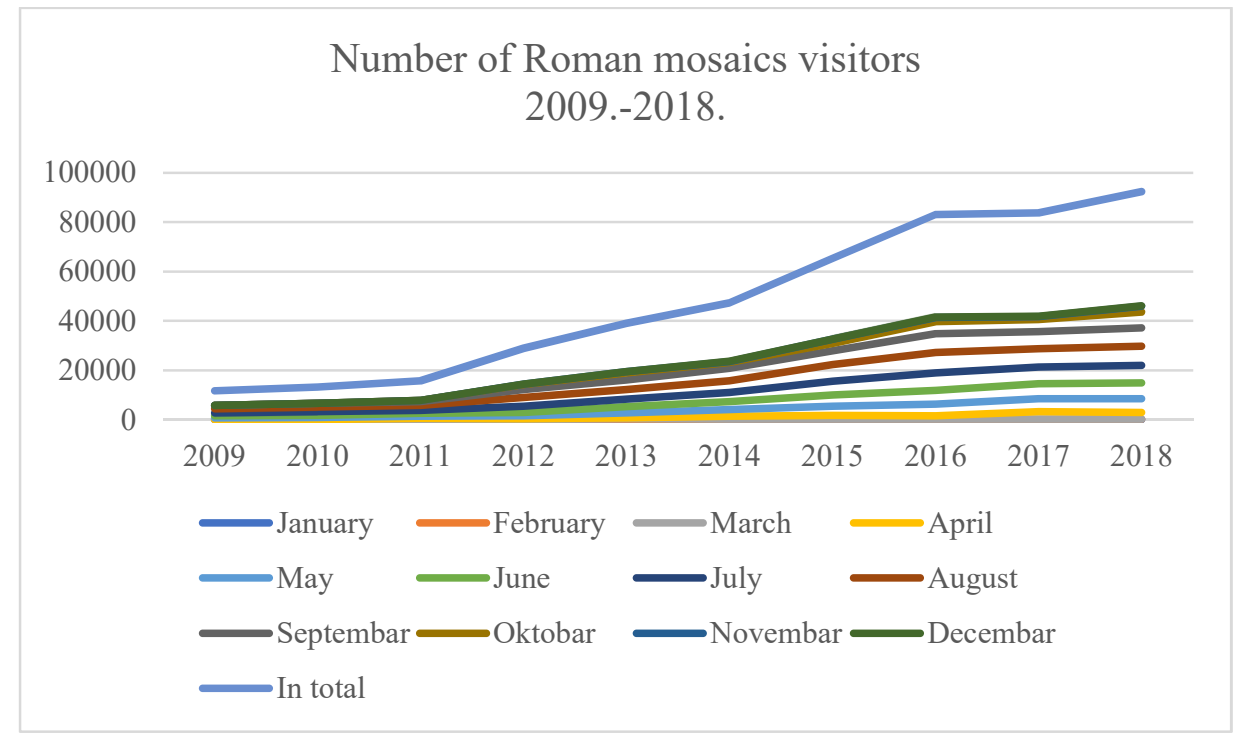

Fig. 1. Cruise ship traffic through Kotor port in the period 2009-2018

It is evident that the largest number of cruise ships comes in November (17.45\%), followed by August (15.18\%) and July (14.22\%). The fewest arrivals are recorded in the first months of the year. Thus, the main tourist cruising season lasts nine months (from May to November), and the ships in the port of Kotor (Luka Kotor A.D., (2019), Dokumentacija o dolasku brodova $i$ jahti u luku Kotor, Kotor), starting from 2010, stay throughout the calendar year. Most ships in the observed period were recorded in 2016 (488) and at least 2008 (228). In the previous year, 2018, Kotor was on the itinerary of 46 cruise lines, with 411 cruise ships bringing 402,475 tourists to the port.

\section{Kotor-Risan tourist excursions}

It was pointed out earlier that tourists during their cruise voyage are offered numerous excursions to nearby localities, which enable them to get acquainted with cultural monuments, the history of the area, the tradition of the local population, culinary specialties, sports attractions and the like.

The following is a summary of the excursion that takes place on the part of the cultural and historical area of the Bay of Kotor, which is protected by UNESCO, on the route Kotor-Risan. The program includes a tour of the site with panoramic buses, two of which are attractive double buses. There are four sites and two museums visited along the hop-on, hop-off route. The attractiveness of the offer is reflected in a visit to the historic center of the old town of Kotor. When touring the city, with guides, tourists get comprehensive information about the rich history of the city with the possibility of visiting religious and cultural-historical monuments. On the site of the Tower of Bajo, between Kotor and Perast, it is possible to enjoy sunbathing and swimming on the sandy beach. The organization of excursions on the mentioned route was started by the company "Open Tour" from Kotor. Later in 2015, Montenegro Shorex was included in this offer. The basic data for the mentioned entities, which are contained in the Central Registry of Business Entities of Montenegro (CRPS), are listed: 
- KOTOR OPEN TOUR a company with headquarters in Kotor (Stari grad b.b.) was established with the aim of providing tour operator activities (reg.no.506296749. Date of first registration is 07.05.2012 and

- MONTENEGRO SHOREX, as a limited liability company with mixed capital, was incorporated on 03.12.2013 (Reg. No. 50679108). The founders of the company are: Company for production, export-import "Kotor open tour" d.o.o. Kotor with $60 \%$ share; "Port of Kotor", a joint stock company for international maritime transport services - Kotor with a founding stake of $30 \%$ and Carrocerias ayats, Spain, whose stake is $10 \%$.

An important segment of the offer on the aforementioned route is the archeological site with beautiful Roman mosaics, which will be discussed in more detail below.

The presentation and care of the archeological site of Risan, as part of its core business, is carried out by the Kotor Tourist Organization. In accordance with the legal decisions regarding the competence of local government in Montenegro, the Municipality in accordance with the law and other regulations: "Regulates, organizes and creates conditions and takes care of tourism development, as well as the development of activities that promote tourism development". Based on these legal starting points, the Decision of the Municipal Assembly of Kotor established this Organization, which started operating in this organizational form in 2005, while the last amendments to the Statute were in 2016. (Ministarstvo održivog razvoja i turizma, (2004), Zakona o turističkim organizacijama (Sl. list RCG 11/04 i 46/07, Sl.

list CG“ 45/04), Skupština Opštine Kotor - Izmjene i dopune Statuta Turističke organizacije Opštine Kotor)

The following is an overview of the number of visitors to this site since its availability (2009), ending with the previous year, 2018.

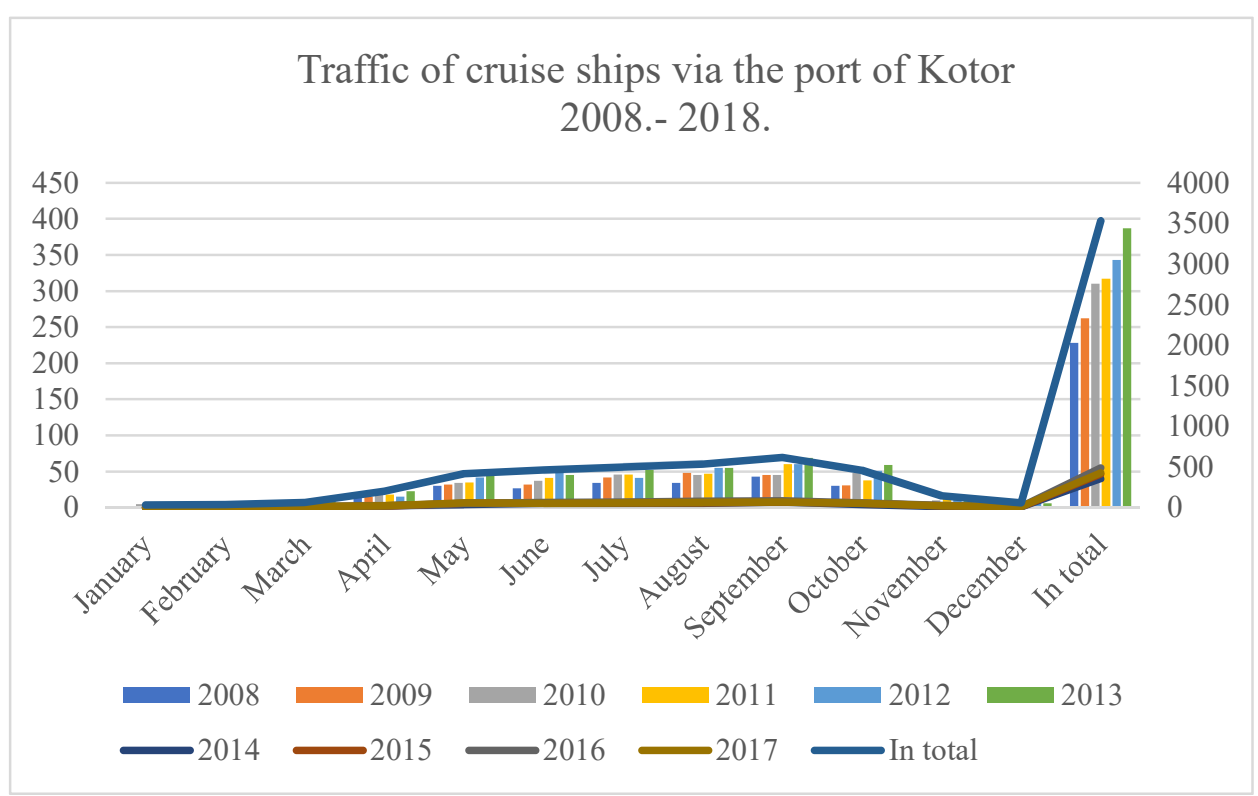

Fig. 2. Graphic representation of the number of Roman mosaic visitors in the period 20082018 (Chart made on the basis of data obtained from the Kotor Tourism Organization)

During this period, 240,128 tourists visited the Roman mosaics. The number of visits to the site, except for 2013 , is in continuous growth $(5,833$ visitors were recorded in the first year and 46,188 in the last observed year). Most tourists visit Roman mosaics during the month 
of August (19.73\%), followed by September (18.44\%) and July (16.54\%). The smallest number of visitors interested in the visit is the beginning of the year: in January only 281 visitors visited the Risan Mosaics, and 292 in February.

The importance of organizing trips from the port of Kotor to Risan is evident from the data contained in the table below, which contains systematic data on the monthly number of visitors to Roman mosaics in the period 2009-2018.

Table 1. Number of Roman mosaic visitors who came organized from cruise ships from the port of Kotor for the period 2012-2018 (Table data obtained from Kotor Tourism

Organization, 2019)

\begin{tabular}{|l|l|l|l|l|l|l|l|l|l|l|l|}
\hline & \multicolumn{9}{|c|}{ Godina } \\
\cline { 2 - 11 } & 2012 & 2013 & 2014 & \multicolumn{2}{|c|}{2015} & \multicolumn{2}{|c|}{2016} & \multicolumn{2}{|c|}{2017} \\
\hline Firm & OT* & OT & OT & OT & MS** & OT & MS & OT & MS & OT & MS \\
\hline Pax. & 4.624 & 8.111 & 11.052 & 14.311 & 8.508 & 12.670 & 17.240 & 13.903 & 14.014 & 14.036 & 13.891 \\
\hline In total & & & & 14.311 & 8.508 & & & & & & \\
\hline $\begin{array}{l}\text { All } \\
\text { together }\end{array}$ & 4.624 & 8.111 & 11.052 & \multicolumn{2}{|c|}{22.819} & \multicolumn{2}{|c|}{29.910} & \multicolumn{2}{|c|}{27.917} & \multicolumn{2}{|c|}{27.927} \\
\hline
\end{tabular}

Since the introduction of the "'Hop-on Hop-off' system, visits to Roman mosaics have increased more than six times. At the same time, the participation of organized visits in this way reaches from $30 \%$ to $60 \%$ of the total number of people who visit the ancient archeological site and mosaics in Risan at the year level. The destination significantly increased the number of visitors after the organized excursion from the port of Kotor, so that the number of visitors analysing the data on the participation of visitors in the period from the beginning of organizing the visit to the mosaics by the system "Hop on - Hop off" (2009), concludes. It should be emphasized that the organization of these excursions, in addition to the fee paid by the Tourist Organization on the basis of the tickets collected, also generates significant income for the community arising from the existence and operation of the business entities that organize the excursion (material costs of using the vehicles, compensation for salaries of employees, fees for businesses...) as well as those made by guests during the trip (ticket prices, fees for purchased refreshments, souvenirs and other necessities...).

\section{Risan and Roman mosaics}

In order to understand the increase in interest and the number of visits to Risan and its ancient archeological site and Roman mosaics, it is necessary to emphasize its historical and cultural values.

According to historical data of historians, unique is the fact that Risan is the oldest settlement in Bay of Boka Kotorska and one of the oldest settlements on the eastern coast of the Adriatic Sea.

The oldest mentions of Risan, as Rizon, is found in Chapters 24 and 25 of the Ancient Greek Geographical Tract "Periplus" from the 4th or 6th century BC, by Pseudo Scylax, which mentions the Enhelei tribe, located around the Rizin River. "Periplus" is the first work of ancient geography intended for seafarers and provides valuable information on the location of settlements and ports in the area under cultivation. The first mention of Risan as a city is found in Polobi (ca. 205 - ca. 120 B.C.) by a Hellenic historian, who calls it Rizon and mentions it in connection with the war of the Romans against Queen Teuta in 229 B.C. Titus Livius (59 BC - $17 \mathrm{BC}$ ), one of the most famous Roman historians in listing the tribes exempt from tax (tribute) after the Romans' victory over the Illyrian king Genci in $168 \mathrm{BC}$, mentions the conquered lands in Illyricum, including the Rhizonitae tribe and the city of Rhizon whom calls it "Urbus opportunus" (pleasant city). Pliny the Elder (23-79) records Risan as Rhisinium or Risinum. Pliny the Younger (63-113 AD) mentions Risan as a 
fortified city of Roman citizens. Claudius Ptolemy (118-161 or 180 AD), a Greek geographer, astronomer, and mathematician, determined the geographical coordinates of Risan (approximate today), referring to it as Risinon ${ }^{\dagger}$.

The oldest development of Risan today, through archeological sites, can be traced back to the ancient period. At the top of Gradina hill, there are the remains of an Illyrian Hellenic fortress, above which are steep karst hillsides as protection and the riverbed of the river Spila, in the lowland part of the settlement. The Roman cultural layer, which is predominantly represented at the Carine site (the area below Gradina, next to the river Spila to the seashore), retracts under the sea, due to the geological and seismic sinking of the coast, and extends into the field as far south as the settlement.

The remains of an ancient Roman villa with mosaics dating from the 2 nd century, at the opposite end of present-day Risan (near today's hospital), which were declared a cultural property and placed under the protection of the state in 1949, testify to the expanse of the Roman city of Rizon (Risan). The remains of a representative ancient building were discovered in 1930 and are located in the southeastern part of the city. The area of the investigated building, measuring approximately $38 \mathrm{~m}$ x $30 \mathrm{~m}$, was cut in the southeast corner by a local road. It consists of an atrium and a series of rooms with mosaic flooring. The Risan mosaics cover the floors of a fancy Roman mansion dating back to the Emperor Hadrian from 2nd century AD. The first research, started in 1930, was conducted by Dušan Vuksan, and the mosaics themselves are first mentioned by the French soldier Vila de Somier, in 1920. The archeological remains of the mosaic in Risan represent a specific entity that stands out from its other provisional Roman creations and is therefore unique in the area of Montenegro and the Adriatic coast.

The whole complex is about $792 \mathrm{~m}^{2}$ and consists of a rectangular central space from which further rectangular rooms continue along a separate corridor. On the east side are five rooms connected by a passage. Floor decorations consist of mosaics of black, gray and white with central and lateral figures in the form of squares, rhombuses and semicircles.

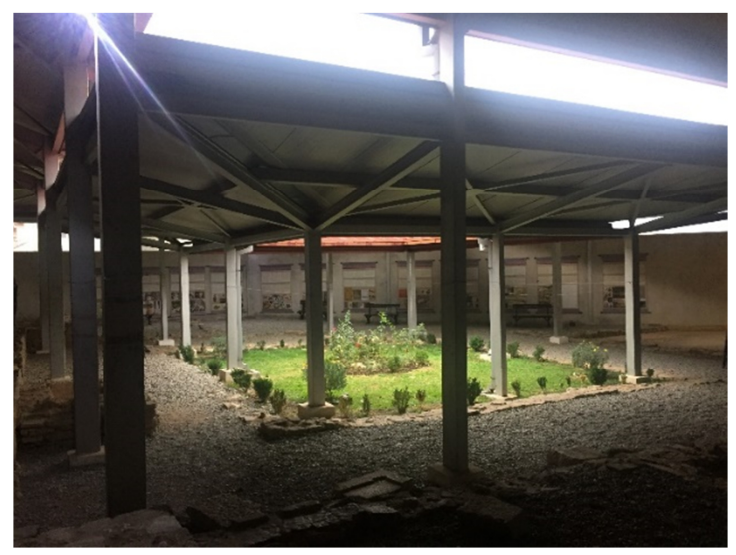

Fig. 1. Complex of archeological site of Roman villa in Risan (Foto: Radovic G.)

What gives this mosaic a special beauty and value is the medallion, which is located in the center, surrounded by black pebbles with woven white meanders. In the medallion is a figure of a man, representing the "God of sleep" - Hypnos. 

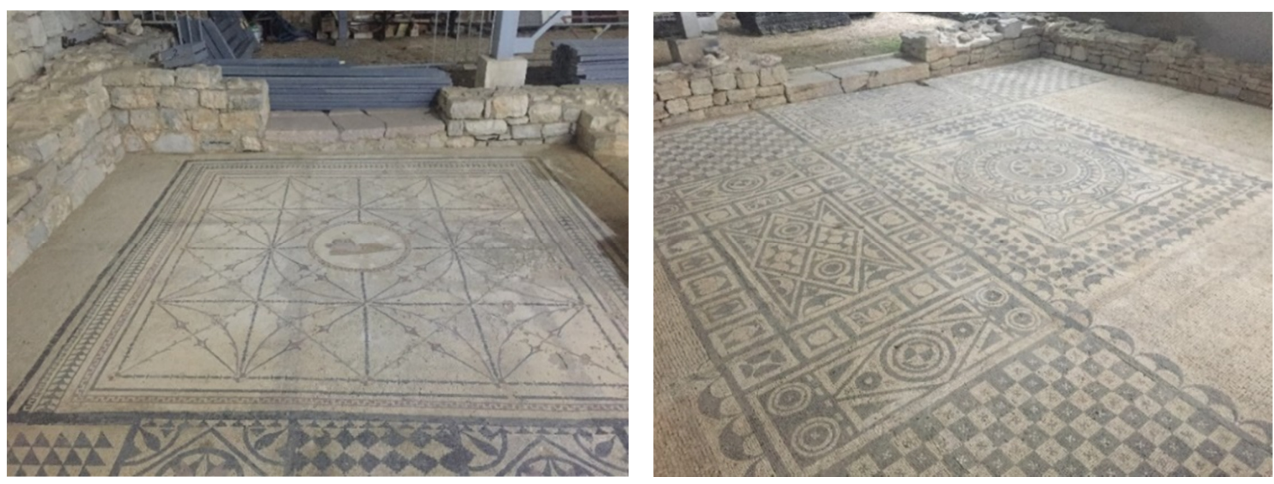

Fig. 2. The representation of the God of Hypnos Fig. 3. Mosaic of the floor of one of the rooms on a cartoon mosaic (Foto: Radovic G.)

The mosaics are arranged in four rooms, made of natural stone cubes in the technique "opus teselatum". It is dominated by geometric motifs with stylized floral ornaments. It is dominated by white, gray and dark colors, while from the figure shows it is the only representation of the Greek dream god Hypnos.

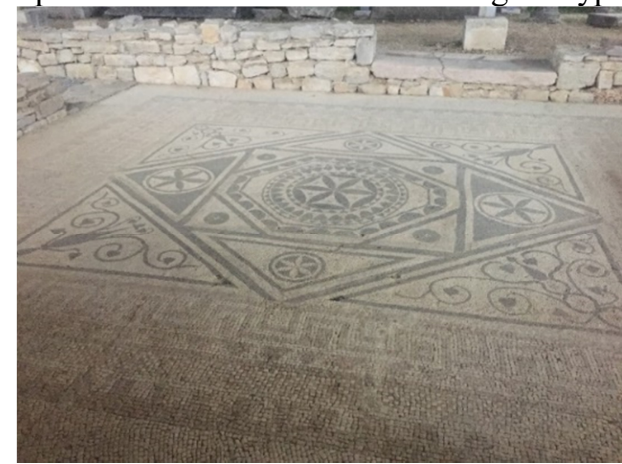

Fig. 4. Floor mosaic of one of the rooms (Foto: Radovic G.)

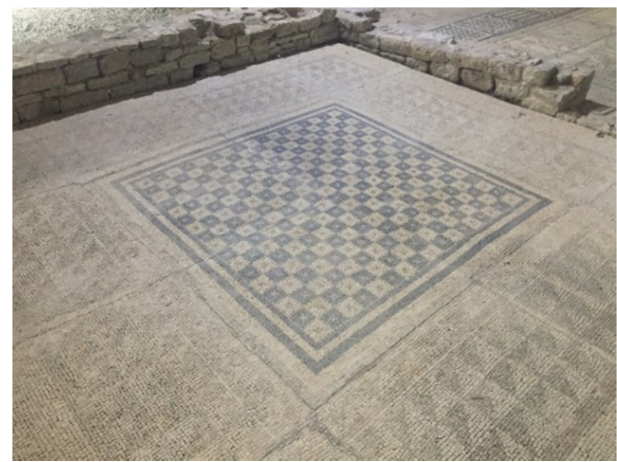

Fig. 5. Floor mosaic of one of the rooms (Foto: Radovic G.)

The entire building was built of thin, pressed local stone bound with lime mortar. The inside of the walls, and probably the outside, were plastered. Based on the fragments of mortar, with traces of painted decoration, preserved on the east wall of the large courtyard, it can be assumed that the other walls of the room were similarly decorated. The painted decoration is made of linear ornaments in white on a red plaster base. It seems likely that the walls of the other rooms were richly decorated with painted ornaments, which, along with the mosaic floors, contributed to the villa's unusually luxurious appearance ( Marković Č., Vujičić R., (1997), Spomenici kulture Crne Gore, Presmedij - Republički zavod za zaštitu spomenika

kulture, Novi sad - Cetinje, 1997. str. 260, 261)

Roman mosaics from II century BC in Risan, they are already known to the scientific world as the most beautiful specimens of this type of art discovered in our country. In beauty, they do not fall behind the famous mosaics of Emperor Hadrian's villa in Tibur (Tivoli), now at the Museo Nazionale in Rome ( Grafički Zavod Hrvatske, (1970), Kotor, Vid Lešić, don Nikol Luković, Skulptura i slikarstvo, Zagreb. str.100) 


\section{Conclusion}

The cultural landscape of the Bay of Boka Kotorska with its unique aesthetics, as a symbiosis of the multi-millennial activity of man and nature, with its wonderful contrasts, characteristics and richness of natural and cultural heritage, represent a strategic potential for contemporary economic development, development of tourism and culture in this area.

The port of Kotor enables the stay of the ship in the immediate vicinity of the city centers, which opens the possibility for travelers to use their stay in Kotor to visit cultural monuments. The data on the increased number of visitors to the ancient site in Risan, presented on the pages of this paper, indicate the increasing interest of cruise tourists in learning about the cultures and history of other peoples and territories, as well as their importance for the site.

- The number of tourists who choose to visit Roman mosaics during their stay in the port of Kotor ranged from 4,624 in 2012 to a record 29,910. tourists transported in 2016. (an average of 18,908 tourists), or rather, averaging a median of 22,819 tourists.

- The number of visitors to Mosaics has increased significantly since the introduction of the organized visit at the beginning of 2012 when 4,624 visitors were recorded through the Open Tour operator, which represents $32.03 \%$ of the total. In 2018 , out of a total of 46,188 tourists who visited the mosaics, $60,46 \%$ came organized (through "Open tour" $(14,036)$ and "Montenegroshorex" $(13,891)$.

- Out of the total number of arriving passengers in the port of Kotor in $2012(245,400)$ of them $(1.88 \%)$ decided to spend part of their time on a trip from Kotor to Risan, and in 2016 this percentage was 5, 88\%, while in 2018 of the total number of 4092,475 passengers, $5.67 \%$ using this excursion.

The priority for the future development of Risan and the Bay of Kotor must be the promotion of cultural tourism. The archeological site in Risan with Roman mosaics makes one of the most significant potential for the development of cultural tourism in Risan and the Bay. In addition, the notion of cultural tourism is no longer tied to a narrow cultural elite but has become a global phenomenon. As the market for cultural tourism grows, its focus is rapidly changing from a preoccupation with monuments and sites to a much broader phenomenon. Consumption of cultural tourism is thus no longer limited to visits to reputable cultural sites but has become part of the "atmosphere" of the destination, created jointly by tourists and locals alike.

In this case, the development of cultural tourism is actively involved in the port of Kotor with the program of cruise tourism, the city administration of Kotor and the locals of Risan. The engagement of all, contributed to the aforementioned results of the number of cruise tourists visiting the ancient site and Roman mosaics in Risan, which significantly contributed to the positioning of Kotor and Risan on the tourist map of tourist destinations with cultural tourism.

\section{References}

1. Dyczek P., (2014), Rhizon, Center for Research on the Antiquity of Southeastern Europe - University of Warsaw, Warsaw-Risan, str. 47-49.

2. Grafički Zavod Hrvatske, (1970), Kotor, Vid Lešić, don Nikol Luković, Skulptura i slikarstvo, Zagreb.

3. Ilija Zorić, (1931), Almanah - Šematizam Zetske Banovine, Sarajevo

4. Luka Kotor A.D., (2019), Dokumentacija o dolasku brodova i jahti u luku Kotor, Kotor. 
5. Marković Č., Vujičić R., (1997), Spomenici kulture Crne Gore , Presmedij Republički zavod za zaštitu spomenika kulture, Novi sad - Cetinje, 1997.

6. MedCruise (2019-20), Yearbook, MedCruise Association, Muelle Ribera S/N Ed. Puerto-Ciudad, 5B Santa Cruz de Tenerife, 38001 Canary Islands, Spain

7. Ministarstvo kulture, (2011), Menadžment plan Prirodnog i kulturno-istorijskog područja Kotora,Cetinje.

8. Ministarstvo održivog razvoja i turizma, (2004), Zakona o turističkim organizacijama (Sl. list RCG 11/04 i 46/07, Sl. list CG“ 45/04),

9. Regionalni Zavod za zaštitu spomenika kulture Kotor, (1982), Studija Graditeljskog nasljeđe Risna, Geneza naselja - analize stanja - uslovi za obradu, Kotor.

10. Turistička organizacija Kotor, Izvještaji o posjeti Rimskim Mozaicima, Opština Kotor.

11. Vučenović S., (2009), Studija “Tretman nepokretnih kulturnih dobara u prostornom

12. planu i GUP- u , Regionalni zavod za zaštitu spomenika kulture Kotor.

13. Uprava za zaštitu kulturnih dobara - Područna jedinica Kotor, (2015), Studija zaštite kulturnih dobara na području Opštine Kotor, Kotor.

14. www.pretraga.crps.me:8083/, 2019. 